\title{
Physico-Chemical, Sensory and Microbiological Quality Characteristics of Tray Packaged Chicken Nuggets Wrapped with Different Films and Stored at Frozen Condition
}

\author{
Dipak Kumar Banerjee, Immanuel Prince Devadason*, Sanjod Kumar Mendiratta, \\ Ravi Kant Agrawal and V. Dhineshkumar
}

Division of Livestock Products Technology, ICAR-IVRI, Izatnagar, Bareilly, UP-243122, India

*Corresponding author

\section{A B S T R A C T}

\section{Keywords}

Tray, Chicken nuggets, LDPE, LLDPE, HDPE, PVC, Polypropylene, frozen

Article Info

Accepted:

07 June 2019

Available Online:

10 July 2019
In the last decade most of the developed countries entered into a new packaging trend called tray packaging which was unexplored in India especially for meat and meat products. The current study was designed to evaluate influence of low density polyethylene (LDPE), linear low density polyethylene (LLDPE), high density polyethylene (HDPE) and polyvinylchloride (PVC) wrap films on various physicochemical $(\mathrm{pH}$, instrumental colour, water activity, Warner-Bratzler shear force, free fatty acid, TBARS and tyrosine value), sensory and microbiological (total plate count, yeast and mold count, coliform count and psychrophilic count) attributes of chicken nuggets at frozen $\left(-18 \pm 2^{\circ} \mathrm{C}\right)$ conditions. About $200 \mathrm{~g}$ of chicken nuggets were aerobically packed separately in food grade polypropylene trays, heat sealed and studied at 1 month interval for 3 months. In frozen storage, chicken nuggets had good qualities in case of all the treatment films for a period of 3 months. Tray packaged chicken nuggets sealed with HDPE film had better physicochemical, sensory and microbiological qualities but nuggets sealed with PVC film had better colour $(L, a, b)$ characteristics than that of other films. Thus, it can be concluded that tray packaging of meat products sealed with HDPE film can be successfully used under frozen conditions for maintenance of better quality of meat products.

\section{Introduction}

Meat and meat products are considered to be an important component in healthy diet all around the world. According to ICMR recommendation the meat consumption should be $10.8 \mathrm{~kg}$ meat per person per annum. Among different meat, chicken is regarded as the universal meat as it is not having any religious taboos. Besides that, poultry contributes nearly half $(47.32 \%)$ of total meat production of India (BAH \& FS, 2018). Acceptance of processed chicken is on the rise, particularly in the urban markets. With the rise in consumer awareness and requirement for hygienic and safe food, processing will have a bright future in the poultry industry in the years to come. 
Rising consumer health-consciousness proved to be a key factor influencing on the development of packaged food in India. Concern about the hygiene status of unpackaged food was a significant factor in encouraging the uptake of packaged products (Euromonitor International, 2016).

Packaging is the last function of the processing chain and first function of the marketing chain. On average, around $25 \%$ of the ex-factory cost of consumer foods is for their packaging. This provides the incentive and the challenge for food packaging technologists to design and develop attractive packages at minimum cost. In the selection of suitable packaging materials for a particular food including meat and meat products, the focus is typically on the barrier properties of the packaging material. Plastic is the most rapidly expanding sector of packaging materials, despite being the newcomer when one reviews historical development. Moisture and gas barrier properties of plastics determine their suitability to ensure the required shelf life of the product (Emblem, 2012). The degrees of protection provided by plastic packaging films depend mainly on the physicochemical quality of the polymers of which they are made of. The factors that affect the shelf life and stability of meat and poultry are numerous, complex, and interconnected.

The ability of modern food retail outlets, such as supermarkets to market a wide range of products is dependent on the shelf life of the products (Ashley, 1985). Therefore, food processors give considerable attention to extend the shelf lives of their products (Robertson, 2010). Inadequate shelf life often leads to consumer dissatisfaction and complaints. Such dissatisfaction eventually affects the acceptance and sales of branded products. Deterioration in meat and meat products qualities can result in economic losses due to consumer rejection of the product. Therefore the maintenance of quality throughout the supply and transportation chain by proper packaging is very much important because this can only ensure the supply of good quality products to the consumers. But the major constraint in marketing of fresh and processed meat including poultry and poultry products is the proper packaging method.

Nowadays due to changes in life styles and with the increased demand for minimally processed foods, studies for case-ready packaging of food products gained popularity. Trend toward case ready meat packaging to reduce back store labour is observed nowadays in the retail market (Belcher, 2006). Packaging innovations have been developed to meet the needs for convenience, but have largely been implemented outside of the meat industry (Eilert, 2005).

During last few decades most of the developed countries entered into a new packaging trend in which trays with the food is wrapped with shrink films due to its series of benefits. Tray packaging with wrap films is the commonest form of packaging of meat and meat products in most of the developed nations. The major benefits of tray packaging include good appeal because of clarity in product visibility from outside, extended shelf life compared to simple flexible plastic packaging, proper labelling of the product, ease in product storage and transportation and increased product demand.

Among the processed meat products, chicken nuggets are having great demand among the consumers. At present nuggets are packaged in a simple low density polyethylene (LDPE) bags and marketed under refrigerated or frozen conditions. Most of the time, due to printing and labelling the inside products are not visible to the consumers. It creates confusion in the minds of the consumers regarding the quality of the products. 
Even though tray packaging is used for packaging of different food products such as vegetables and fruits, fish and bakery items, its usage for meat and meat products packaging is unexplored in India. Tray packaging of meat and meat products in India is still in its juvenile stage and requires lots of research to identify the best combination of tray and wrap films at different combinations. The most commonly used polymers for food packaging are LDPE, high density polyethylene (HDPE), polypropylene (PP) and polyamide (PA) (Jan et al., 2005). Polyesters (PET), polyvinyl chloride (PVC), polyvinylidene chloride (PVdC), polystyrene (PS) and ethylene/vinyl acetate (EVAC) are also used in food packaging (Marsh and Bugusu, 2007). Among all these films LDPE is the most commonly used film for wrapping purpose due to its easy availability and cost factor but it is inferior to many other films such as HDPE, LLDPE and PVC food grade films. These films are having better barrier properties to block moisture and oxygen and also having better puncture resistance and sealing properties, thereby expected to have more strength as well as capacity to extend the shelf life.

With the above listed advantages of tray packaging for better life and consumer acceptance, this study has been initiated with the objective to determine the physicochemical, sensorial and microbial quality characteristics of chicken nuggets in tray packaging using different wrap films viz LDPE, LLDPE, HDPE and PVC at frozen temperature $\left(-18^{\circ} \pm 2^{\circ} \mathrm{C}\right)$.

\section{Materials and Methods}

\section{Sources of materials}

The chicken was procured from Post-Harvest Technology (PHT) Division, Indian Council of Agricultural Research - Central Avian
Research Institute (ICAR-CARI), Izatnagar, Bareilly, UP. Food Safety and Standards Authority of India (FSSAI) approved spices, sugar powder, refined salt, corn flour and refined oil were procured from local market of Bareilly. Onion and garlic were also procured from local market of Bareilly for preparation of condiment paste (onion: garlic=3:1). All the media, chemicals (analytical grade), plastic wares and glass wares for laboratory use were also procured from standard firms (Hi-Media, Sisco Research Laboratories Pvt. Ltd. (SRL), Tarson, Borosil etc.). Food grade polypropylene trays with a dimension of $19 \times 14 \times 3 \mathrm{~cm}(\mathrm{LxWxH})$ and different food grade flexible films like LDPE, HDPE, LLDPE and PVC were purchased from local market of Bareilly to use as packaging materials.

\section{Preparation of nuggets}

Chicken nugget was prepared as per the procedure outlined by Anjaneyulu et al., (1989). Briefly, meat was collected from PHT Division, ICAR-CARI and kept under frozen storage at $-18 \pm 2{ }^{\circ} \mathrm{C}$ till further processing. Before processing, meat was thawed and cut into small cubes and minced twice (first through a $6 \mathrm{~mm}$ grinding plate followed by 4 mm plate) using a meat mincer (Seydelmann, Germany).

For meat emulsion preparation, salt, sugar, phosphate, nitrite were thoroughly mixed to the pre-weighed quantity of minced meat in a bowl chopper (Seydelmann K20 Ras 99221-1, Germany) and ice flakes were added during chopping to maintain lower temperature $\left(8 \pm 2^{\circ} \mathrm{C}\right)$. Oil was added after two minutes followed by condiments, dry spice mix and refined wheat flour and chopping was continued till uniform mixing of all ingredients. Above emulsion was steam cooked for 40 minutes, cooled and sliced under good manufacturing practices. 


\section{Packaging and storage study}

About 200g of chicken nuggets were aerobically packed in food grade PP trays using LDPE, HDPE, LLDPE and PVC wrap films and heat sealed. The chicken nuggets were stored at frozen condition $\left(-18 \pm 2^{\circ} \mathrm{C}\right)$ and evaluated for physico-chemical, sensorial and microbiological qualities at 1 month interval upto 3 months for comparing the efficacy of different wrap films.

\section{Analytical procedures}

\section{Physicochemical parameters}

\section{pH}

$\mathrm{pH}$ was determined by the method of Trout et al., (1992). $5 \mathrm{~g}$ of sample was blended with 45 $\mathrm{ml}$ of distilled water using Ultra Turrax Tissue Homogeniser (Model T-25, Janke and Kunkel, 1KA Labor Technik, Germany) for $1 \mathrm{~min}$. The $\mathrm{pH}$ of homogenates was measured by immersing combined glass electrode of digital pH meter (Edge, Hanna, Romania).

\section{Instrumental colour}

Colour profile was measured using Hunter Lab (Portable type, 703.471.6870, USA). The instrument was calibrated using black and white tiles provided with the instrument. Hunter ' $L$ ' (brightness(100)/lightness(0)), ' $a$ ' (redness(+)/greenness(-)) and ' $b$ ' (yellowness(+)/blueness(-)) values were recorded directly on a uniform layer of nuggets at three different points.

\section{Water activity $\left(\mathbf{a}_{\mathbf{w}}\right)$}

Water activity was measured with the help of a dew point water activity meter (4TE, Aqualab). The sample was placed in the sample container up to $1 / 2$ to $3 / 4$ th level and introduced inside the sample chamber. The water activity was recorded in 'quick mode' and recorded after the beep sound.

\section{TBARS value}

The TBARS value was determined by using the distillation method described by Tarladgis et al., (1960). $10 \mathrm{gm}$ of sample was homogenized with $50 \mathrm{ml}$ distilled water using Ultra Turrax Tissue Homogeniser (Model T25, Janke and Kunkel, 1KA Labor Technik, Germany) for 2 minutes and quantitatively transferred to a $500 \mathrm{ml} \mathrm{Kjeldahl} \mathrm{flask.} \mathrm{After}$ rinsing with $45 \mathrm{ml}$ of distilled water, washings were transferred to the flask and $5 \mathrm{ml}$ of $6 \mathrm{~N}$ Hydrochloric acid $(\mathrm{HCl})$ was added to it. Few drops of liquid paraffin and glass beads were added to prevent frothing and bumping respectively, during heating. The flask was heated to high temperature and $50 \mathrm{ml}$ distillate was collected in a graduated stopper glass cylinder. The distillate was thoroughly mixed and $5 \mathrm{ml}$ of distillate was pipetted in duplicate into $20 \mathrm{ml}$ glass stopper test tubes. $5 \mathrm{ml}$ of TBA (0.02M 2-thiobarburic acid in 90\% glacial acetic acid) was added to each test tube. The contents were mixed well and immersed in boiling water bath for 30 minutes. A blank consisting of $5 \mathrm{ml}$ of distilled water and $5 \mathrm{ml}$ of TBA reagent was similarly prepared. The tubes were cooled for 10 minutes under tap water and optical density was recorded using spectrophotometer (10S UV-VIS, Genesys, Thermoscientific) at 538 $\mathrm{nm}$. The O.D. was multiplied by the factor 7.8 and TBARS value was expressed as $\mathrm{mg}$ malonaldehyde $/ \mathrm{kg}$ of sample.

\section{Tyrosine value}

The procedure of Strange et al., (1977) was followed. $2 \mathrm{~g}$ of sample was blended with 10 $\mathrm{ml}$ of precooled 20\% Trichloroacetic acid (TCA) solution for 2 minutes in an Ultra Turrax Tissue Homogeniser (Model T-25, Janke and Kunkel, 1KA Labor Technik, 
Germany). The homogenate was filtered through the Whatmann filter paper No. 42 and TCA extract was collected in a test tube. 2.5 $\mathrm{ml}$ of TCA extract was mixed with equal amount of water and $10 \mathrm{ml}$ of freshly prepared $0.5 \mathrm{~N}$ sodium hydroxide and kept for 10 minutes. Then $3 \mathrm{ml}$ of Folin and Ciocalteus reagent (FC reagent and distilled water in the ratio of 1:2) was added, shaken well and kept undisturbed for 30 minutes in a dark place for colour development. The optical density of mixture was measured at $730 \mathrm{~nm}$. Tyrosine value was calculated as mg of tyrosine per 100 $\mathrm{g}$ meat sample by referring to a standard graph.

\section{Warner-Bratzler shear force}

The shear force value was determined by the method of Berry and Stiffler (1981). Nuggets were cut into $1 \mathrm{~cm}^{3}$ cubes. The shear force was measured on Warner-Bratzler apparatus (Model: 81031307, G.R. Elect MFG Co., USA) at a crosshead speed of $2 \mathrm{~mm} / \mathrm{s}$. The average values $\left(\mathrm{kg} / \mathrm{cm}^{2}\right)$ for each sample was recorded as a mean of triplicates.

\section{Free fatty acid (FFA) value}

The method as described by Koniecko (1979) was followed. $5 \mathrm{~g}$ sample was blended with one teaspoonful anhydrous sodium sulphate and $30 \mathrm{ml}$ of chloroform using Ultra Turrax Tissue Homogeniser (Model T-25, Janke and Kunkel, 1KA Labor Technik, Germany) for 2 minutes. The slurry was filtered through Whatman filter paper No.1 into a conical flask. About 2-3 drops of $0.2 \%$ phenolphthalein indicator solution was added to the chloroform extract, which was then titrated against $0.1 \mathrm{~N}$ alcoholic potassium hydroxide to get the pink colour at end point.

The quantity of the potassium hydroxide required for titration was recorded and free fatty acid (\%) was calculated as follows:
$0.1 \times \mathrm{ml}$ of $\mathrm{KOH}$ consumed $\times 0.282$

Free fatty acid $(\%)=$---------------------- $\times 100$

Weight of sample (g)

\section{Sensory evaluation}

A six member experienced panel of judges consisting of faculty and postgraduate students of the LPT Division, ICAR-IVRI, Izatnagar evaluated the samples around 3.30-4.00 pm for the attributes of colour and appearance, flavour, texture, juiciness and overall acceptability using an 8 point descriptive scale (Keeton, 1983), where $8=$ =xtremely desirable and $1=$ extremely undesirable. Nugget samples were warmed in a microwave oven for 30 seconds. Plain drinking water at room temperature was provided to each panel member to rinse the pallet before tasting of each sample.

\section{Microbiological quality}

All the microbiological parameters were determined as per the methods described by American Public Health Association (APHA, 2001). Preparation and serial dilution of samples were done near the flame in a laminar flow unit (Model: Airstream, ESCO class II $\mathrm{BSC}$ ). About $10 \mathrm{~g}$ of sample was aseptically weighed and homogenized for 2 minutes in a sterile mortar containing $90 \mathrm{ml}$ of $0.1 \%$ sterile peptone water to make $10^{-1}$ dilution. $1 \mathrm{ml}$ of $10^{-1}$ dilution was mixed with $9 \mathrm{ml}$ of $0.1 \%$ peptone water to obtain $10^{-2}$ dilution and so on. Duplicate sets of petridishes were inoculated aseptically with $1 \mathrm{ml}$ of aliquots from appropriate dilutions.

Different readymade dry media from HiMedia Laboratories Pvt. Ltd. was used for the enumeration of different microbes. Plates showing 30-300 colonies were counted. The number of colonies were multiplied with reciprocal of the dilution and expressed as $\log _{10} \mathrm{cfu} / \mathrm{g}$. 


\section{Total plate count}

In $1000 \mathrm{ml}$ of distilled water, $23.5 \mathrm{~g}$ plate count agar (M091) was dissolved and autoclaved at $15 \mathrm{lb}$ pressure at $121^{\circ} \mathrm{C}$ for 15 minutes. About $20 \mathrm{ml}$ of plate count agar having $\mathrm{pH} 7.0 \pm 0.2$ at $44-46^{\circ} \mathrm{C}$ was poured gently in to each dish and rotated in clockwise and anticlockwise directions for 7-8 times to mix the media uniformly. The plates were incubated at $37 \pm 1^{\circ} \mathrm{C}$ for 48 hours.

\section{Psychrophilic count}

The plates were prepared similar to that of total plate count but incubated at $4 \pm 1^{\circ} \mathrm{C}$ for 14 days.

\section{Coliform count}

In $1000 \mathrm{ml}$ of distilled water, $41.53 \mathrm{~g}$ Violet Red Bile agar (VRBA) was suspended and boiled for 2 minutes. About $12-15 \mathrm{ml}$ of the agar at $44-46^{\circ} \mathrm{C}$ was poured gently in to each dish and rotated in clockwise and anticlockwise directions for 7-8 times to mix the media uniformly. The plates were incubated at $35^{\circ} \mathrm{C}$ for 48 hours.

\section{Yeast and mould count}

Thirty nine gram of potato dextrose agar (PDA, Code No: M096) was dissolved in 1000 $\mathrm{ml}$ of distilled water and autoclaved. Then it was cooled and acidified with $10 \mathrm{ml}$ of $10 \%$ sterilized tartaric acid solution to adjust the $\mathrm{pH}$ to 3.5. About $20 \mathrm{ml}$ of PDA at $44-46^{\circ} \mathrm{C}$ was poured gently into each petridish and incubated at $25^{\circ} \mathrm{C}$ for 5-7 days. Black, white, yellow and greenish black colonies were counted.

\section{Statistical analysis}

The present study was replicated thrice and in each replication, measurements of all parameters were done in triplicate. Sensory evaluation was performed by a panel of six member judges three times, so total observations being $18 \quad(n=18)$. The analysis was carried out using SPSS software (version 20.0) and data were analysed using two-way ANOVA where treatment and storage time as main effects. Statistical significance were identified at the $95 \%$ confidence level $(\mathrm{P}<0.05)$. The values were presented as mean along with standard error (Mean \pm Standard Error).

\section{Results and Discussion}

\section{Physico-chemical parameters}

\section{pH}

A gradual increase in the $\mathrm{pH}$ values of chicken nuggets in case of all the packaging materials was noticed during storage (Table 1). The initial value of chicken nuggets was 6.19 which increased to $6.42,6.44,6.50,6.41$ in HDPE, LDPE, LLDPE and PVC packaged nuggets respectively at the end of frozen storage for 3 months. But the $\mathrm{pH}$ of nuggets packaged under HDPE was significantly $(\mathrm{P}<0.05)$ lower than that of other films at $2^{\text {nd }}$ month of storage which might be due to the better gas barrier property of HDPE. The $\mathrm{pH}$ of LLDPE packaged chicken nuggets were significantly higher $(\mathrm{P}<0.05)$ throughout the whole storage study. This increase in $\mathrm{pH}$ during storage could be due to protein breakdown and liberation of protein metabolites, mainly amines due to bacterial activity during storage (Jay, 1996). A slight increase in $\mathrm{pH}$ from 6.39 to 6.45 during frozen storage of 90 days is also reported by Das et al., (2008) in goat meat nuggets.

\section{Instrumental colour}

Colour of meat and meat products is very important from the consumer point of view. 
Lightness $(L)$, redness $(a)$ and yellowness $(b)$ of chicken nuggets showed significant changes during the storage period (Fig. 1-3). All the $L, a$ and $b$ values decreased with storage time in this frozen study. During first month of storage lightness was highest for PVC packaged nuggets and lowest for LLDPE packaged nuggets. The decrease in lightness was significantly $(\mathrm{P}<0.05)$ lower in case of nuggets packed with PVC film. The change in redness and yellowness was minimum in PVC packaged nuggets during frozen storage.

The $L, a$ and $b$ values might have decreased because of formation of metmyoglobin which imparted brownish discolouration to the product. Pigment oxidation may facilitate lipid oxidation, and free radicals produced during oxidation may oxidize iron atom or denaturate myoglobin molecules, adversely affecting colour of the meat product. There was a positive correlation in sensory colour score with instrumental colour. Less change in the colour values of PVC packaged nuggets might be attributed to the better gas barrier property of the film. Modi et al., (2006) find no significant changes in $L, a$ and $b$ values of chicken curry during 6 months of frozen storage. Similarly Selani et al., (2011) report a significant decrease in redness value in raw chicken at sixth month of frozen storage. Lavieri and Williams (2014) also report a decrease in yellowness value of ground beef during storage.

\section{Water activity $\left(\mathbf{a}_{\mathbf{w}}\right)$}

The water activity of the chicken nuggets decreased significantly $(\mathrm{P}<0.05)$ in all four groups throughout the storage period of study (Table 2). The initial water activity at 0 day was 0.976 which reduced to 0.933 to 0.942 at the end of study period. The decrease in water activity might be due to the evaporative loss of moisture of product through the films. The water activity of nuggets was highest in case of HDPE and lowest in case of PVC films. This could be attributable to the high moisture barrier property of HDPE. Similarly, water activity of broiler meat nuggets and patties are reduced significantly $(\mathrm{P}<0.05)$ during the storage period of 90 days at frozen condition (Sohaib et al., 2017).

\section{Thiobarbituric Acid Reacting Substances (TBARS) value}

TBARS values of chicken nuggets in all treatment groups had increasing trend with increase in frozen storage period (Fig. 4).

It could be due to the lipid oxidation and production of volatile metabolites in the presence of oxygen attributed to oxygen permeability of packaging material (Brewer $e t$ al., 1992). Nuggets packaged with HDPE had lowest and LLDPE packaged nuggets had highest TBARS value during frozen storage. This could be due to lower gas transmission rate of HDPE leading to less oxidative changes of the nuggets. Similarly, there is significant increase in TBARS value of goat meat nuggets during 90 days of frozen storage (Das et al., 2008)

\section{Tyrosine value (TV)}

Tyrosine value is an index of degree of autolytic and bacterial proteolysis occurring in the meat and meat products. Tyrosine values of chicken nuggets in all treatment groups exhibited an increasing trend (Table 3). But there was no significant difference among the products packaged with different films. Increase in tyrosine value could be attributed to hydrolytic changes in meat by tissue and bacterial enzymes (Strange et al., 1977). Similarly, Nath et al., (2016) observe a significant $(\mathrm{P}<0.05)$ increase in tyrosine value of chicken nuggets during 60 days of frozen storage at $-18 \pm 1^{\circ} \mathrm{C}$. 
Fig.1 Effect of different wrap films on Colour-lightness $(L)$ of chicken nuggets stored at $-18 \pm 2^{\circ} \mathrm{C}$

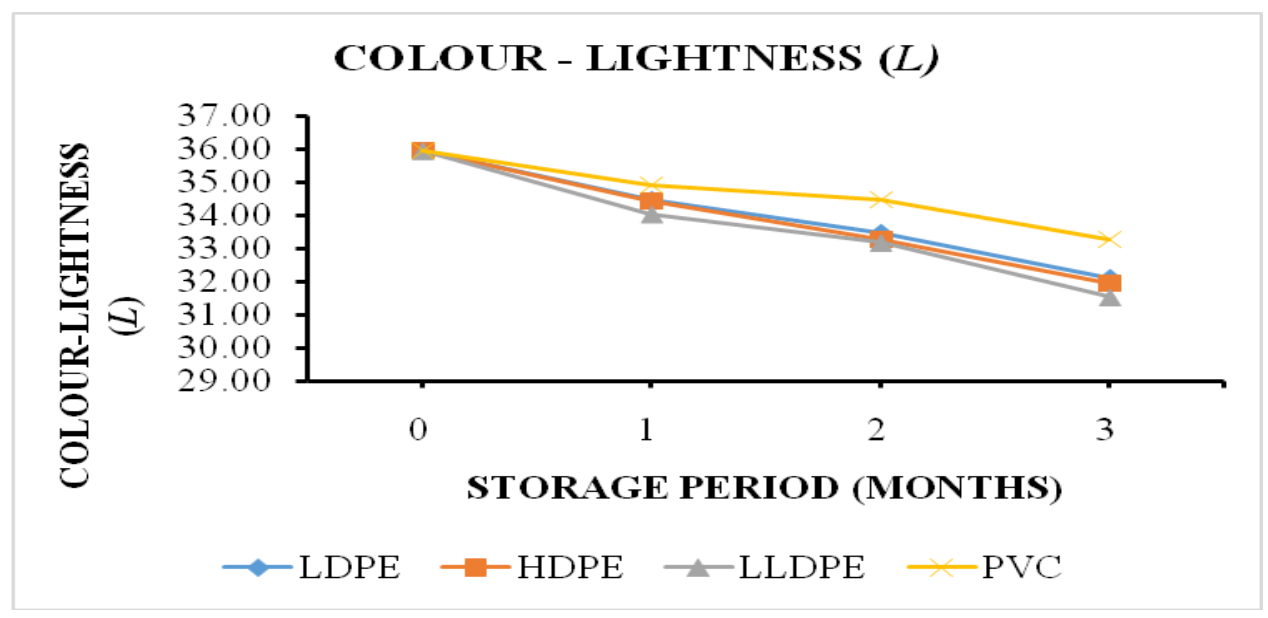

Fig.2 Effect of different wrap films on Colour-redness $(a)$ of chicken nuggets stored at $-18 \pm 2^{\circ} \mathrm{C}$

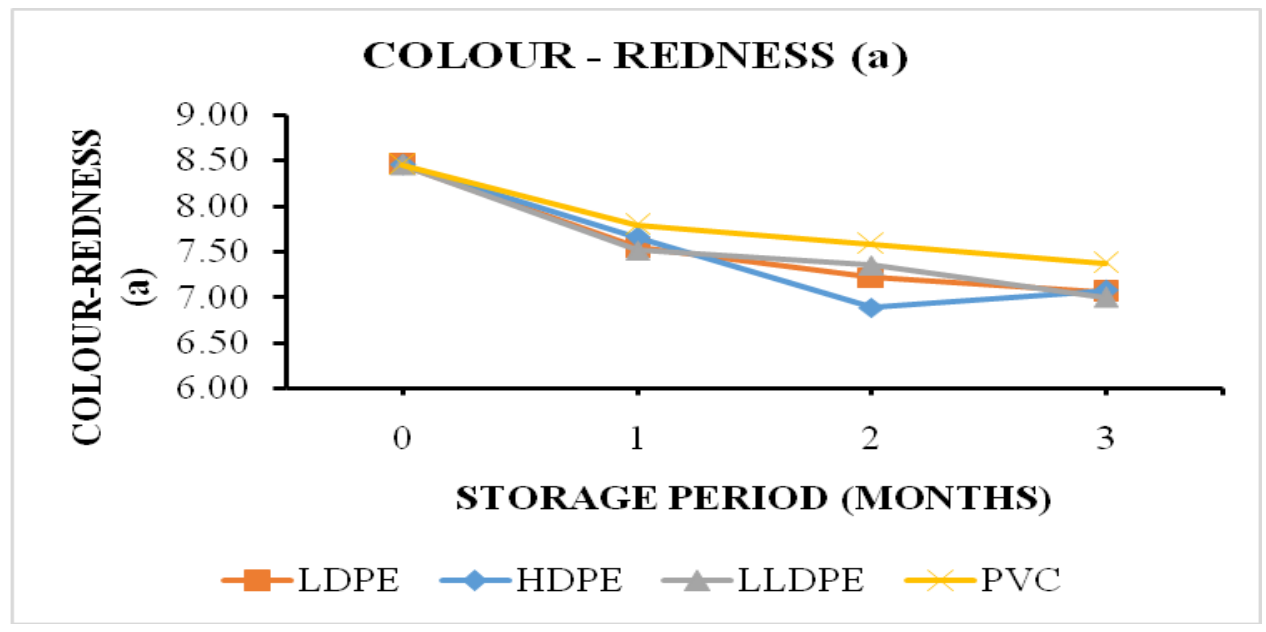

Fig.3 Effect of different wrap films on Colour-yellowness $(b)$ of chicken nuggets stored at $18 \pm 2^{\circ} \mathrm{C}$

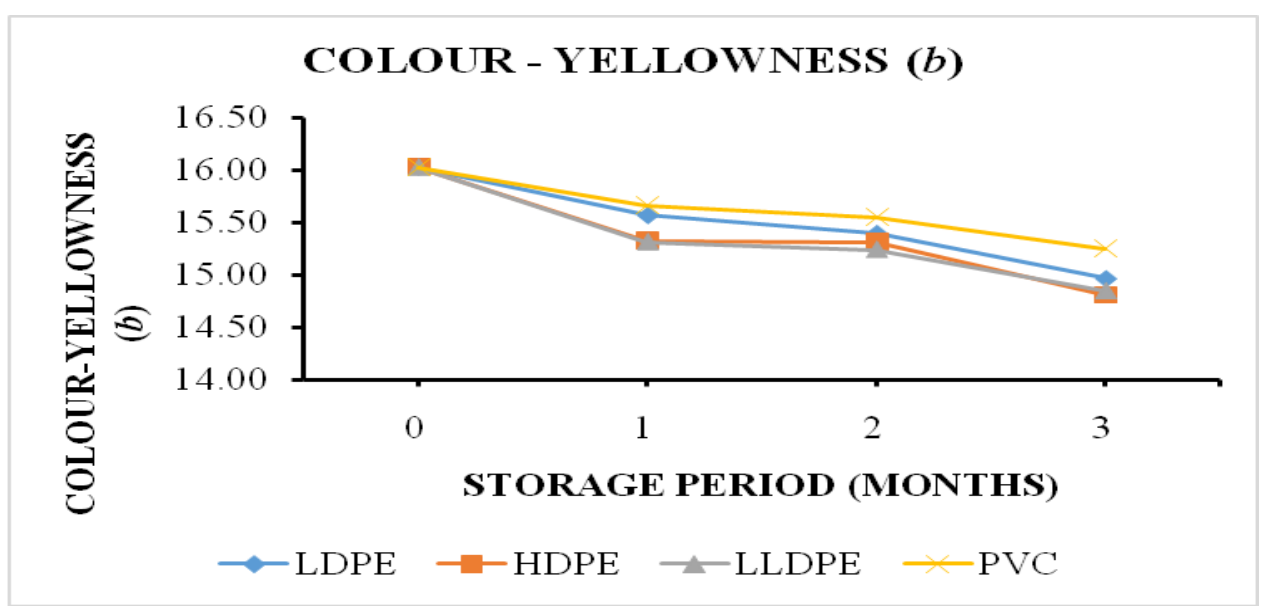


Fig.4 Effect of different wrap films on TBARS value of chicken nuggets stored at $-18 \pm 2^{\circ} \mathrm{C}$

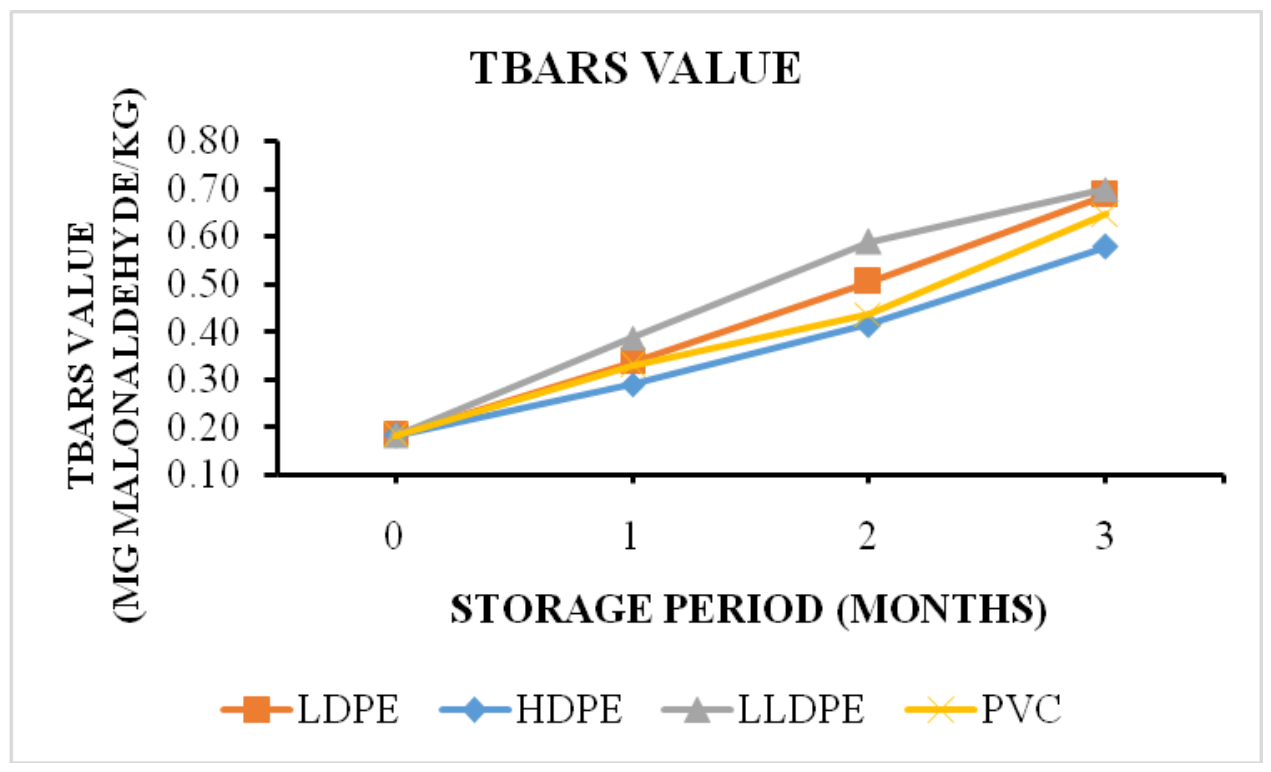

Fig.5 Effect of different wrap films on free fatty acid of chicken nuggets stored at $-18 \pm 2^{\circ} \mathrm{C}$

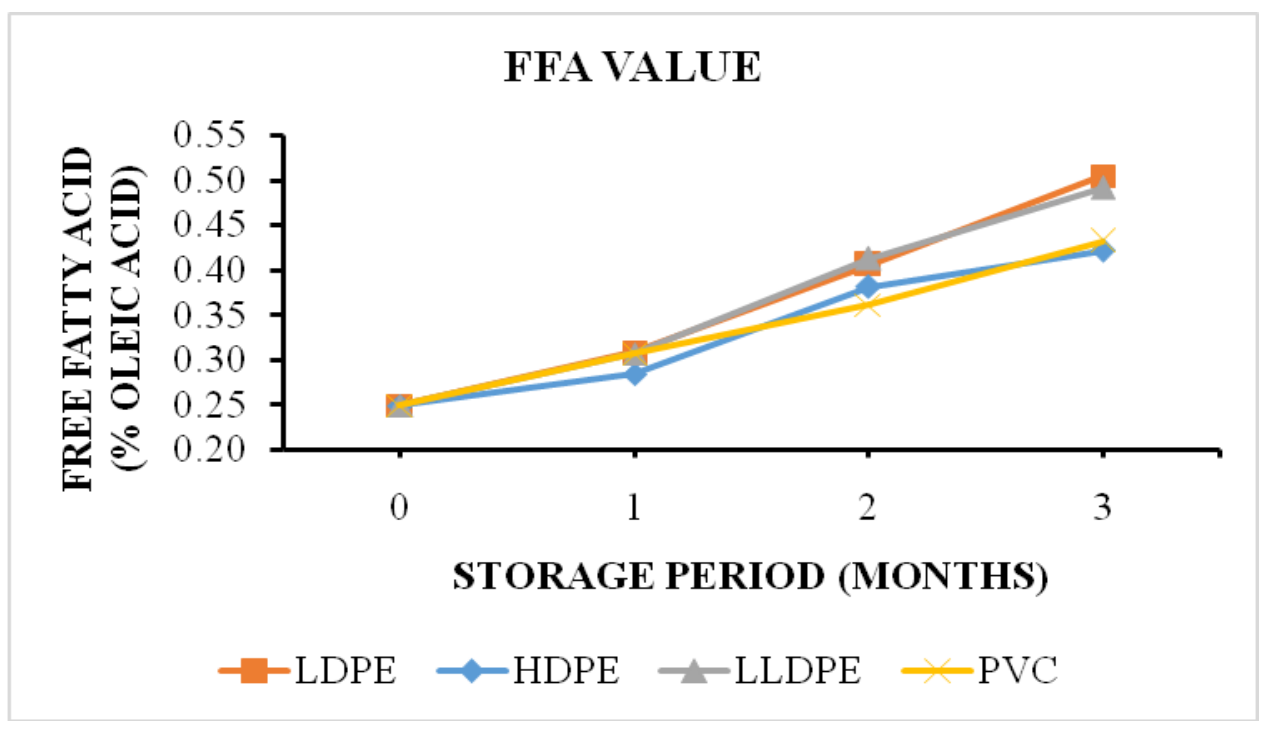

\begin{tabular}{|c|c|c|c|c|}
\hline \multicolumn{5}{|c|}{ Table.1 Effect of different wrap films on $\mathbf{p H}$ of chicken nuggets stored at $\mathbf{- 1 8} \pm \mathbf{2}^{\circ} \mathbf{C}$} \\
\hline $\begin{array}{c}\text { Treatment } \\
\text { (Polyilms) }\end{array}$ & 0 & 1 & 2 & 3 \\
\hline LDPE & $6.19 \pm 0.008^{\mathrm{a}}$ & $6.28 \pm 0.008^{\mathrm{bA}}$ & $6.38 \pm 0.008^{\mathrm{cB}}$ & $6.44 \pm 0.007^{\mathrm{dA}}$ \\
\hline HDPE & $6.19 \pm 0.008^{\mathrm{a}}$ & $6.24 \pm 0.007^{\mathrm{bA}}$ & $6.32 \pm 0.006^{\mathrm{CA}}$ & $6.42 \pm 0.006^{\mathrm{dA}}$ \\
\hline LLDPE & $6.19 \pm 0.008^{\mathrm{a}}$ & $6.32 \pm 0.006^{\mathrm{bB}}$ & $6.43 \pm 0.007^{\mathrm{CC}}$ & $6.50 \pm 0.011^{\mathrm{dB}}$ \\
\hline PVC & $6.19 \pm 0.008^{\mathrm{a}}$ & $6.27 \pm 0.012^{\mathrm{bA}}$ & $6.36 \pm 0.008^{\mathrm{cAB}}$ & $6.41 \pm 0.006^{\mathrm{dA}}$ \\
\hline
\end{tabular}

Mean \pm S.E. with different superscripts row wise (small alphabet) and column wise (capital alphabet) differ significantly $(\mathrm{P}<0.05)$. $\mathrm{N}=9$ for each treatment. 


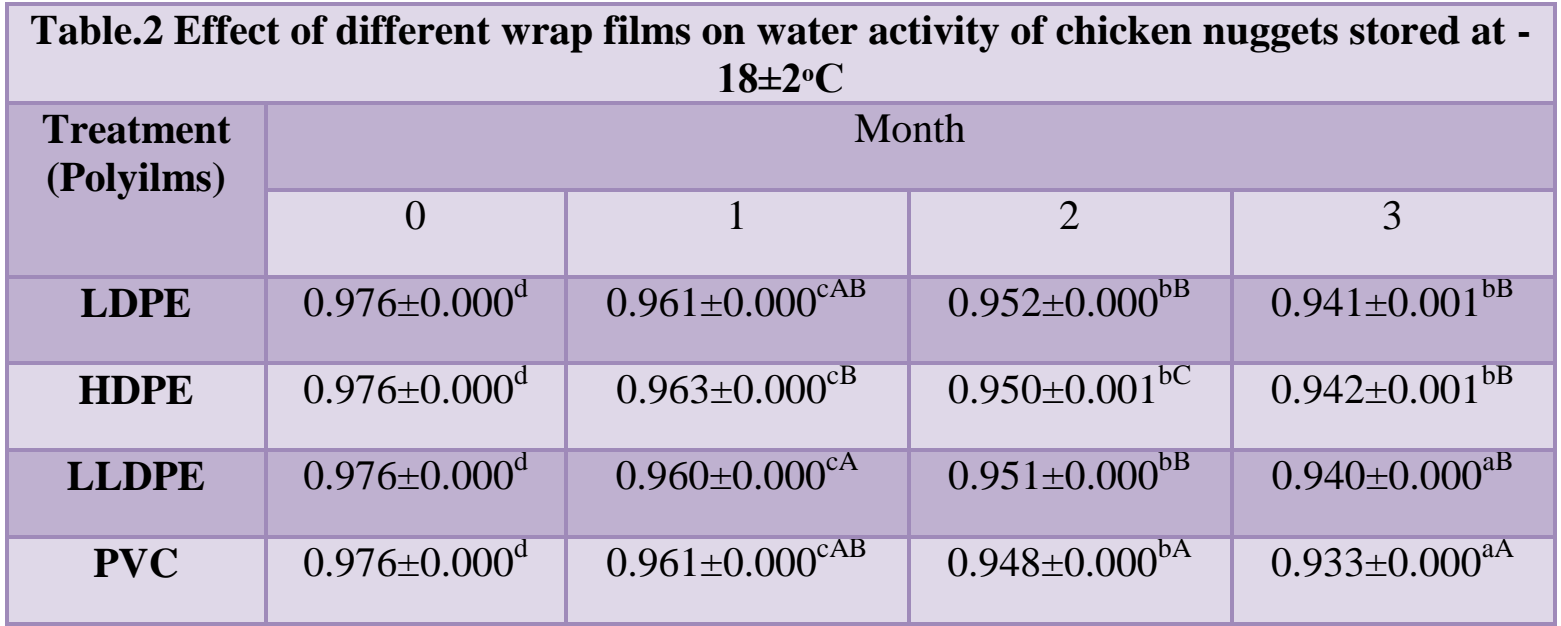

Mean \pm S.E. with different superscripts row wise (small alphabet) and column wise (capital alphabet) differ significantly $(\mathrm{P}<0.05)$. $\mathrm{N}=9$ for each treatment.

\begin{tabular}{|c|c|c|c|c|}
\hline \multicolumn{5}{|c|}{ Table.3 Effect of different wrap films on Tyrosine Value (mg/g) of chicken nuggets } \\
stored at $\mathbf{- 1 8} \pm \mathbf{2}^{\circ} \mathbf{C}$ \\
\hline \multirow{2}{*}{$\begin{array}{c}\text { Treatment } \\
\text { (Polyilms) }\end{array}$} & \multicolumn{4}{|c|}{ Month } \\
\cline { 2 - 5 } & 0 & 1 & 2 & 3 \\
\hline LDPE & $0.21 \pm 0.010^{\mathrm{a}}$ & $0.25 \pm 0.008^{\mathrm{b}}$ & $0.28 \pm 0.011^{\mathrm{bc}}$ & $0.31 \pm 0.010^{\mathrm{c}}$ \\
\hline HDPE & $0.20 \pm 0.009^{\mathrm{a}}$ & $0.26 \pm 0.011^{\mathrm{b}}$ & $0.27 \pm 0.008^{\mathrm{b}}$ & $0.29 \pm 0.010^{\mathrm{b}}$ \\
\hline LLDPE & $0.20 \pm 0.009^{\mathrm{a}}$ & $0.25 \pm 0.008^{\mathrm{b}}$ & $0.29 \pm 0.008^{\mathrm{bc}}$ & $0.31 \pm 0.006^{\mathrm{c}}$ \\
\hline PVC & $0.20 \pm 0.009^{\mathrm{a}}$ & $0.24 \pm 0.008^{\mathrm{ab}}$ & $0.27 \pm 0.008^{\mathrm{bc}}$ & $0.29 \pm 0.008^{\mathrm{c}}$ \\
\hline
\end{tabular}

Mean \pm S.E. with different superscripts row wise (small alphabet) and column wise (capital alphabet) differ significantly $(\mathrm{P}<0.05)$. $\mathrm{N}=9$ for each treatment.

\begin{tabular}{|c|c|c|c|c|}
\hline \multicolumn{5}{|c|}{ Table.4 Effect of different wrap films on shear force value $\left(\mathbf{K g} / \mathbf{c m}^{2}\right)$ of chicken } \\
nuggets stored at $\mathbf{- 1 8 \pm 2 ^ { \circ } \mathbf { C }}$ \\
\hline $\begin{array}{c}\text { Treatment } \\
\text { (Polyilms) }\end{array}$ & \multicolumn{4}{|c|}{ Month } \\
\hline & 0 & 1 & 2 & 3 \\
\hline LDPE & $0.43 \pm 0.014^{\mathrm{c}}$ & $0.36 \pm 0.013^{\mathrm{b}}$ & $0.31 \pm 0.013^{\mathrm{ab}}$ & $0.26 \pm 0.013^{\mathrm{a}}$ \\
\hline HDPE & $0.43 \pm 0.014^{\mathrm{c}}$ & $0.36 \pm 0.014^{\mathrm{b}}$ & $0.32 \pm 0.014^{\mathrm{b}}$ & $0.27 \pm 0.012^{\mathrm{a}}$ \\
\hline LLDPE & $0.43 \pm 0.014^{\mathrm{c}}$ & $0.34 \pm 0.016^{\mathrm{b}}$ & $0.29 \pm 0.018^{\mathrm{ab}}$ & $0.25 \pm 0.014^{\mathrm{a}}$ \\
\hline PVC & $0.43 \pm 0.014^{\mathrm{c}}$ & $0.35 \pm 0.014^{\mathrm{b}}$ & $0.30 \pm 0.014^{\mathrm{ab}}$ & $0.26 \pm 0.013^{\mathrm{a}}$ \\
\hline
\end{tabular}

Mean \pm S.E. with different superscripts row wise (small alphabet) and column wise (capital alphabet) differ significantly $(\mathrm{P}<0.05)$. $\mathrm{N}=9$ for each treatment. 
Table.5 Effect of different wrap films on sensory attributes of chicken nuggets stored at $-18 \pm 2^{\circ} \mathrm{C}$

\section{Colour and appearance}

\begin{tabular}{|c|c|c|c|c|}
\hline \multirow{2}{*}{$\begin{array}{c}\text { Treatment } \\
\text { (Polyilms) }\end{array}$} & \multicolumn{4}{|c|}{ Month } \\
\cline { 2 - 5 } & 0 & 1 & 2 & 3 \\
\hline LDPE & $7.71 \pm 0.043^{\mathrm{d}}$ & $7.04 \pm 0.071^{\mathrm{c}}$ & $6.01 \pm 0.061^{\mathrm{bA}}$ & $5.56 \pm 0.065^{\mathrm{aA}}$ \\
\hline HDPE & $7.71 \pm 0.043^{\mathrm{d}}$ & $7.25 \pm 0.064^{\mathrm{c}}$ & $6.72 \pm 0.092^{\mathrm{bB}}$ & $6.08 \pm 0.102^{\mathrm{aB}}$ \\
\hline LLDPE & $7.71 \pm 0.043^{\mathrm{d}}$ & $7.01 \pm 0.076^{\mathrm{c}}$ & $5.99 \pm 0.057^{\mathrm{bA}}$ & $5.51 \pm 0.055^{\mathrm{aA}}$ \\
\hline PVC & $7.71 \pm 0.043^{\mathrm{d}}$ & $7.03 \pm 0.073^{\mathrm{c}}$ & $6.01 \pm 0.060^{\mathrm{bA}}$ & $5.57 \pm 0.063^{\mathrm{aA}}$ \\
\hline
\end{tabular}

\section{Flavour}

\section{Treatment}

(Polyilms)

LDPE

HDPE

LLDPE

PVC

\begin{tabular}{|c|c|c|c|}
\hline \multicolumn{4}{|c|}{ Month } \\
\hline 0 & 1 & 2 & 3 \\
\hline $7.64 \pm 0.046^{\mathrm{d}}$ & $6.95 \pm 0.075^{\mathrm{c}}$ & $5.97 \pm 0.070^{\mathrm{bA}}$ & $5.55 \pm 0.066^{\mathrm{aA}}$ \\
\hline $7.64 \pm 0.046^{\mathrm{d}}$ & $7.19 \pm 0.067^{c}$ & $6.69 \pm 0.097^{\mathrm{bB}}$ & $6.06 \pm 0.103^{\mathrm{aB}}$ \\
\hline $7.64 \pm 0.046^{d}$ & $6.96 \pm 0.078^{c}$ & $5.98 \pm 0.061^{\mathrm{bA}}$ & $5.46 \pm 0.056^{\mathrm{aA}}$ \\
\hline $7.64 \pm 0.046^{\mathrm{d}}$ & $6.99 \pm 0.068^{\mathrm{c}}$ & $5.99 \pm 0.066^{\mathrm{bA}}$ & $5.54 \pm 0.070^{\mathrm{aA}}$ \\
\hline
\end{tabular}

Treatment

(Polyilms)

\begin{tabular}{|c|c|c|c|c|}
\hline LDPE & $7.68 \pm 0.042^{\mathrm{c}}$ & $7.01 \pm 0.079^{\mathrm{b}}$ & $5.98 \pm 0.059^{\mathrm{a}}$ & $5.51 \pm 0.070^{\mathrm{a}}$ \\
\hline HDPE & $7.68 \pm 0.042^{\mathrm{b}}$ & $7.25 \pm 0.059^{\mathrm{b}}$ & $6.30 \pm 0.383^{\mathrm{a}}$ & $6.03 \pm 0.082^{\mathrm{a}}$ \\
\hline LLDPE & $7.68 \pm 0.042^{\mathrm{c}}$ & $6.97 \pm 0.084^{\mathrm{b}}$ & $5.95 \pm 0.070^{\mathrm{a}}$ & $5.48 \pm 0.055^{\mathrm{a}}$ \\
\hline PVC & $7.68 \pm 0.042^{\mathrm{c}}$ & $6.99 \pm 0.078^{\mathrm{b}}$ & $5.98 \pm 0.070^{\mathrm{a}}$ & $5.52 \pm 0.065^{\mathrm{a}}$ \\
\hline & \multicolumn{3}{c}{} \\
\hline
\end{tabular}

\section{Treatment}

(Polyilms)

LDPE

HDPE

\section{LLDPE}

PVC

\begin{tabular}{|c|c|c|c|}
\hline \multicolumn{4}{|c|}{ Month } \\
\hline 0 & 1 & 2 & 3 \\
\hline $7.67 \pm 0.042^{\mathrm{d}}$ & $6.96 \pm 0.099^{\mathrm{c}}$ & $5.96 \pm 0.078^{\mathrm{bA}}$ & $5.46 \pm 0.047^{\mathrm{aA}}$ \\
\hline $7.67 \pm 0.042^{\mathrm{d}}$ & $7.21 \pm 0.065^{\mathrm{c}}$ & $6.69 \pm 0.102^{\mathrm{bB}}$ & $6.00 \pm 0.097^{\mathrm{aB}}$ \\
\hline $7.67 \pm 0.042^{\mathrm{d}}$ & $6.95 \pm 0.088^{\mathrm{c}}$ & $5.92 \pm 0.071^{\mathrm{bA}}$ & $5.43 \pm 0.053^{\mathrm{aA}}$ \\
\hline $7.67 \pm 0.042^{\mathrm{d}}$ & $6.99 \pm 0.064^{\mathrm{c}}$ & $5.97 \pm 0.069^{\mathrm{bA}}$ & $5.51 \pm 0.071^{\mathrm{aA}}$ \\
\hline
\end{tabular}

\section{Overall acceptability}

\section{Treatment \\ (Polyilms)

LDPE
HDPE
LLDPE
PVC

Mean \pm S.E. with different superscripts row wise (small alphabet) and column wise (capital alphabet) differ significantly $(\mathrm{P}<0.05)$. $\mathrm{N}=18$ for each treatment. 


\begin{tabular}{|c|c|c|c|c|}
\hline \multicolumn{5}{|c|}{$\begin{array}{l}\text { Table.6 Effect of different wrap films on microbiological } \\
\text { nuggets stored at }-18 \pm 2^{\circ} \mathrm{C}\end{array}$} \\
\hline \multicolumn{5}{|c|}{ Total plate count $\left(\log _{10} \mathrm{cfu} / \mathrm{gm}\right)$} \\
\hline \multirow{2}{*}{$\begin{array}{l}\text { Treatment } \\
\text { (Polyilms) }\end{array}$} & \multicolumn{4}{|c|}{ Month } \\
\hline & 0 & 1 & 2 & 3 \\
\hline LDPE & $2.46 \pm 0.078^{\mathrm{b}}$ & $2.25 \pm 0.100^{\mathrm{ab}}$ & $2.04 \pm 0.070^{\mathrm{a}}$ & $2.02 \pm 0.054^{2}$ \\
\hline HDPE & $2.46 \pm 0.078^{b}$ & $2.30 \pm 0.090^{\mathrm{ab}}$ & $2.10 \pm 0.097^{\mathrm{ab}}$ & $1.97 \pm 0.067^{a}$ \\
\hline LLDPE & $2.46 \pm 0.078^{b}$ & $2.21 \pm 0.064^{\mathrm{ab}}$ & $2.17 \pm 0.085^{\mathrm{ab}}$ & $2.06 \pm 0.065^{\circ}$ \\
\hline PVC & $2.46 \pm 0.078^{b}$ & $2.20 \pm 0.074^{\mathrm{ab}}$ & $2.07 \pm 0.058^{\mathrm{a}}$ & $2.06 \pm 0.079^{a}$ \\
\hline \multicolumn{5}{|c|}{ Psychrophilic count $\left(\log _{10} \mathrm{cfu} / \mathrm{gm}\right)$} \\
\hline \multirow{2}{*}{$\begin{array}{l}\text { Treatment } \\
\text { (Polyilms) }\end{array}$} & \multicolumn{4}{|c|}{ Month } \\
\hline & 0 & 1 & 2 & 3 \\
\hline LDPE & ND & $1.65 \pm 0.048^{\mathrm{a}}$ & $1.85 \pm 0.027^{\mathrm{ab}}$ & $1.96 \pm 0.081^{b}$ \\
\hline HDPE & ND & $1.63 \pm 0.046^{\mathrm{a}}$ & $1.72 \pm 0.057^{\mathrm{ab}}$ & $1.92 \pm 0.054^{\mathrm{b}}$ \\
\hline LLDPE & ND & $1.60 \pm 0.036^{\mathrm{a}}$ & $1.81 \pm 0.057^{\mathrm{ab}}$ & $1.97 \pm 0.048^{b}$ \\
\hline PVC & ND & $1.66 \pm 0.033^{\mathrm{a}}$ & $1.80 \pm 0.049^{\mathrm{ab}}$ & $1.96 \pm 0.072^{b}$ \\
\hline
\end{tabular}

Mean \pm S.E. with different superscripts row wise (small alphabet) and column wise (capital alphabet) differ significantly $(\mathrm{P}<0.05)$. $\mathrm{N}=9$ for each treatment, $\mathrm{ND}=$ Not Detected.

\section{Warner-Bratzler shear force}

There was significantly $(\mathrm{P}<0.05)$ decreasing trend in the Warner Bratzler shear force values of chicken nuggets in case of all the packaging materials during entire storage period (Table 4). The initial value was 0.43 $\mathrm{kg} / \mathrm{cm}^{2}$ which decreased in the range of 0.25 $\mathrm{kg} / \mathrm{cm}^{2}$ to $0.27 \mathrm{~kg} / \mathrm{cm}^{2}$ at the end of storage. But the difference of the shear force values of chicken nuggets with different packaging material was insignificant $(\mathrm{P}>0.05)$ at particular month of frozen storage. This decrease in shear force value during storage could be due to denaturation of proteins and action of bacterial enzymes which can attack more rapidly on already denatured meat protein and can bring about structural disintegration of proteins. Similarly Modi et al., (2006) find marginal decrease of shear force values of meat pieces in chicken curry during 6 months of frozen storage.

\section{Free fatty acid (FFA) value}

The increase in free fatty acid (\% oleic acid) content of chicken nuggets was insignificant $(\mathrm{P}>0.05)$ during the first month of frozen storage (Fig. 5). However, FFA values showed significantly $(\mathrm{P}<0.05) \quad$ increasing trend with the progressive storage period from $1^{\text {st }}$ to $3^{\text {rd }}$ month in case of all the treatment groups, which might be due to lipolysis. There was no significant difference among FFA of chicken nuggets packaged with different films upto $2^{\text {nd }}$ month of storage. Nuggets packaged with HDPE showed a significantly lower FFA value on completion of study period. This could be due to lower gas and water vapour transmission rate of HDPE leading to less oxidative changes of the nugget. Earlier several researchers have also reported the increasing trend of FFA content during storage of meat products. Das et al., (2008) find a significant increase in FFA values during frozen storage of goat meat nuggets for a period of 90 days. There was positive correlation between TBARS values and free fatty acids values since both were related with fat oxidation.

\section{Sensory attributes}

The mean scores for all the sensory attributes in all treatment groups showed a significantly $(\mathrm{P}<0.05)$ decreasing trend with increase in 
frozen storage period (Table 5). There was no significant difference of chicken nuggets packaged with different films on 0 and $1^{\text {st }}$ month of storage for all the sensory attributes and for texture throughout the whole storage period. Although, HDPE packaged nuggets showed a significantly $(\mathrm{P}<0.05)$ higher scores on $2^{\text {nd }}$ and $3^{\text {rd }}$ month of storage for colour and appearance, flavour, juiciness and overall acceptability.

The overall decrease in colour and appearance scores might be due to pigment and lipid oxidation. The progressive decrease in flavour scores could be correlated to an increase in TBARS values and free fatty acids in the meat products (Tarladgis et al., 1960) under aerobic conditions. Decline in texture and juiciness scores could be due to loss of moisture and dehydration which led to hardening of products. The decrease in overall acceptability scores during frozen storage might be reflective of the decline in scores of colour and appearance, flavour, texture, and juiciness attributes. Furthermore, a gradual increase in FFA and TBA values explains the descending trend in the rating of sensory quality of the product during storage, as reported by other workers (Sen and Karim 2003; Andres et al., 2006 and Modi et al., 2009). The decline in sensory scores for all the attributes noticed in the present study is in agreement with the findings of Das et al., (2008) in goat meat nuggets and Modi et al., (2006) in chicken curry during frozen storage.

\section{Microbiological characteristics}

The total plate count decreased slightly throughout the storage period of chicken nuggets in frozen condition (Table 6). The decrease in total plate count on $3^{\text {rd }}$ month was significant compared to fresh nugget at 0 month for all the treatment groups. The psychrophiles were not detected in the fresh product but were present during $1^{\text {st }}, 2^{\text {nd }}$ and $3^{\text {rd }}$ month of storage and showed an increasing trend from $1^{\text {st }}$ to $3^{\text {rd }}$ month of frozen storage. But there was no significant difference of total plate count and psychrophilic count among chicken nuggets packaged with different films during the whole frozen storage. Coliform and yeast and molds were not detected in the nuggets throughout the whole frozen study. Similarly Modi et al., (2006) report a decrease in total plate count from 2.2 to $1.7 \log _{10} \mathrm{cfu} / \mathrm{gm}$ and an increase in psychrophilic count from 1.8 to $2.0 \log _{10} \mathrm{cfu} / \mathrm{gm}$ during first 3 months of frozen storage of chicken curry. Das et al., (2008) also report an increase in psychrotrophic count during the frozen storage of goat meat nuggets. In present study, psychrophilic count remained well below the threshold level of acceptability of cooked meat products that have been reported as $4 \log _{10} \mathrm{cfu} / \mathrm{gm}$ (Jay, 1996) and $4.6 \log _{10}$ cfu/gm (Cremer and Chipley, 1977) upto 3 months of frozen storage indicating that the products were microbiologically good for a frozen storage of 3 months in all the treatment groups. Absence of psychrophilic bacteria in fresh products might be attributed to retardation of log phase as a result of reduced metabolic rate due to sudden change in the physical environment (Kumar, 2015). The coliforms were not detected in products throughout the storage period. It could be due to the destruction of coliforms during cooking at high temperature, much above their death point of $57^{\circ} \mathrm{C}$. Further, hygienic practices followed during handling and packaging of nuggets could also be one of the reasons for the absence of coliforms. Similar results are reported by Sachdev and Gopal (2000) in cooked chicken rolls and Kumar and Sharma (2004) in pork patties. The absence of yeast and molds throughout the period of storage might be due to unfavourable conditions for their growth such as high $\mathrm{pH}$, lower temperature and good hygienic practices followed during the product preparation. 
Chicken nuggets had maintained good quality attributes in case of all the treatment films under frozen condition $\left(-18 \pm 2^{\circ} \mathrm{C}\right)$ for a period of 3 months. Tray packaged chicken nuggets sealed with HDPE films showed better quality than that of LDPE, LLDPE and PVC films but chicken nuggets sealed with PVC film had shown better instrumental colour $(L, a, b)$ characteristics than that of other films. HDPE wrapping film has been found to be more advantageous in preserving the quality characteristics of chicken nuggets under frozen storage.

\section{Acknowledgements}

We are thankful to all the faculty members of the LPT department, Dr. Geeta Chauhan, Dr. Rajiv Ranjan Kumar, Dr. Suman Talukder, Dr. Sagar Chand and Dr. Arvind for their valuable help extended during the course of study. We are highly thankful to the Director, Joint

Director(s)

(Academic/Research/CADRAD), Deemed University, IVRI for providing the necessary facilities to carry out the research work. Sincere thanks to ICAR to provide financial assistance to carry out the research work.

\section{References}

Andres, D. K., Inz, H. and Szmanko, T. 2006. Sensory quality of selected physicochemical properties of processed meat products produced in different plants. Acta Sci Poult Technol Aliment. 52: 93-105.

Anjaneyulu, A.S.R., Sharma, N. and Kondaiah, N. 1989. Evaluation of salt, polyphosphates and their blends at different levels on physicochemical properties of buffalo meat and patties. Meat sci. 25(4): 293-306.

APHA. 2001. Compendium of methods for the microbiological examination of foods. $4^{\text {th }}$ ed. American Public Health
Association, Washington D.C, USA. $600 \mathrm{p}$.

Ashley, R. J. 1985. Permeability and plastics packaging. In: Polymer permeability. Netherlands, Springer. Pp 269-308.

BAH \& FS. 2018. Basic Animal Husbandry and Fisheries Statistics, 2016-17. Department of Animal Husbandry, Dairying and Fisheries. Ministry of Agriculture and Farmers Welfare, Government of India.

Belcher, J. N. 2006. Industrial packaging developments for the global meat market. Meat Sci. 74(1): 143-148.

Berry, B. W. and Stiffler, D. M. 1981. Effects of electrical stimulation, boning temperature, formulation and rate of freezing on sensory, cooking, chemical and physical properties of ground beef patties. J. Food Sci. 46(4): 1103-1106.

Brewer, M. S., Ikins, W. G. and Harbers, C. A. Z. 1992. TBA values, sensory characteristics and volatiles in ground pork during long-term frozen storage: Effect of packaging. J. Food Sci. 57(3): 558-563.

Cremer, M. L. and Chipley, J. R. 1977. Satellite food service system: Time and temperature and microbiological and sensory quality of precooked frozen hamburger patties. Journal of Food Protection. 40(9): 603-607.

Das, A. K., Anjaneyulu, A. S. R., Verma, A. K. and Kondaiah, N. 2008. Physicochemical, textural, sensory characteristics and storage stability of goat meat patties extended with full- fat soy paste and soy granules. International journal of food science \& technology. 43 (3): 383-392.

Eilert, S. J. 2005. New packaging technologies for the 21st century. Meat sci. 71 (1): 122-127.

Emblem, A. 2012. Plastics properties for packaging materials. In: Packaging 
Technology. London, UK, College of Fashion. Pp 287-309.

Euromonitor International. 2016. Packaging Industry in India. $23 \mathrm{p}$. http://www.euromonitor.com/packaging -industry-in-india/report.

Jan, J. H., Zhang, Y. and Buffo, R. 2005. Surface chemistry of food, packaging and biopolymer materials. In: J.H. Han, Editor, Innovations in food packaging, Elsevier Academic Press, Amsterdam, Pp.45-59.

Jay, J. M. 1996. In Modern Food Microbiology. $5^{\text {th }}$ ed. New Delhi, CBS Publishers and Distributors.

Keeton, J. T. 1983. Effect of fat and sodium chloride salt/phosphate level on the chemical and sensory properties of pork patties. J. Food Sci. 48: 878-885.

Konieko, E. K. 1979. In: Handbook for meat chemists. Chap. 6, Avery Publishing Group Inc., Wayne, New Jersey, USA. Pp. 68-69.

Kumar, R. R. and Sharma, B. D. 2004. Storage quality and shelf life of aerobically packaged extended chicken patties. J. Vet. Public Health. 2(1, 2): $35-41$.

Kumar, S. 2015. Quality evaluation of mutton nuggets incorporated with flaxseed flour and essential oils. MVSc Thesis, Indian Veterinary Research Institute, Izatnagar, India.

Lavieri, N. and Williams, S. K. 2014. Effects of packaging systems and fat concentrations on microbiology, sensory and physical properties of ground beef stored at $4 \pm 1 \mathrm{C}$ for 25 days. Meat science. 97(4): 534-541.

Marsh, K. and Bugusu, B. 2007. Food packaging - Roles, materials, and environmental issues. J. Food Sci. 72(3): 39-55.

Modi, V. K., Sachindra, N. M., Sathisha, A. D., Mahendrakar, N. S. and Narasimha Rao, D. 2006. Changes in quality of chicken curry during frozen storage. Journal of muscle foods. 17(2):141-154.

Modi, V. K., Yashoda, K. P., Bhaskar, N. and Mahendrakar, N. S. 2009. Effect of carrageenan and oat flour on storage characteristics of fried mutton kofta. Journal of food processing and preservation. 33(6): 763-776.

Nath, P. M., Kumar, V., Praveen, P. K. and Ganguly, S. 2016. Effect of chicken skin, soy protein and olive oil on quality characteristics of chicken nuggets. Int. J. Sci. Environ. Technol. 5(3): 15741585.

Robertson, G. L. 2010. Food Packaging and Shelf Life. In: Food Packaging and Shelf Life. $p 1$.

Sachdev, A. K. and Gopal, R. 2000. Storage quality changes in cooked chicken rolls. Indian Journal of Poultry Science. 35(3): 364-366.

Selani, M. M., Contreras-Castillo, C. J., Shirahigue, L. D., Gallo, C. R., PlataOviedo, M. and Montes-Villanueva, N. D. 2011. Wine industry residues extracts as natural antioxidants in raw and cooked chicken meat during frozen storage. Meat science. 88(3): 397-403.

Sen, A. R. and Karim, S. A. 2003. Effect of meat particle size on quality attributes of restructured mutton steaks. Journal of food science and technology. 40(4): 423-425.

Sohaib, M., Anjum, F. M., Arshad. M. S., Imran, M., Imran, A. and Hussain, S. 2017. Oxidative stability and lipid oxidation flavoring volatiles in antioxidants treated chicken meat patties during storage. Lipids in Health and Disease. 16: 27.

Strange, E. D., Benedict, R. C., Smith, J. L. and Swift, C. E. 1977. Evaluation of rapid tests for monitoring alterations in meat quality during storage. J. Food Protect. 40(12): 843-847. 
Tarladgis, B. G., Watts, B. M., Yaunathan, M. T. and Dugan, L. R. 1960. Distillation methods for the quantitative determination of malonaldehyde in rancid foods. J. Am. Oil Chem. Soc. 37: 66-71.
Trout, E. S., Hunt, M. C., Johnson, D. E., Claus, J. R., Kastner, C. L. and Kropt, D. H. 1992. Characteristics of low fat ground beef containing texture modifying ingredients. J. Food Sci. 57(1): 19-24.

\section{How to cite this article:}

Dipak Kumar Banerjee, Immanuel Prince Devadason, Sanjod Kumar Mendiratta, Ravi Kant Agrawal and Dhineshkumar, V. 2019. Physico-Chemical, Sensory and Microbiological Quality Characteristics of Tray Packaged Chicken Nuggets Wrapped with Different Films and Stored at Frozen Condition. Int.J.Curr.Microbiol.App.Sci. 8(07): 793-808.

doi: https://doi.org/10.20546/ijcmas.2019.807.096 